\title{
Improved root zone temperature buffer capacity enhancing sweet pepper yield via soil-ridged substrate-embedded cultivation in solar greenhouse
}

\author{
Guohai Fu' ${ }^{1,2}$, Zonggeng $\mathrm{Li}^{1}$, Wenke Liu ${ }^{1 *}$, Qichang Yang ${ }^{1}$ \\ (1. Institute of Environment and Sustainable Development in Agriculture, Chinese Academy of Agricultural Sciences/Key Laboratory of \\ Energy Conservation and Waste Management of Agricultural Structures, Ministry of Agriculture, Beijing 100081, China; \\ 2. National Agricultural Technology Extension and Service Center, Beijing 100125, China)
}

\begin{abstract}
A novel soilless cultivation method, called as soil-ridged substrate-embedded cultivation (SSC) was invented, and an experiment was designed to investigate root zone temperature and production efficiency of sweet pepper cultivated by two SSC patterns, i.e., SSC-P (polyethylene groove inserted) and SSC-W (wire-mesh groove inserted), and also other two cultivation methods, i.e., soil ridge (SR) and naked polyethylene groove (PG). Results showed that PG, SSC-P and SSC-W increased the average minimal root zone temperature by $1.01^{\circ} \mathrm{C}, 0.75^{\circ} \mathrm{C}$, and $1.16^{\circ} \mathrm{C}$ compared to SR $\left(16.33^{\circ} \mathrm{C}\right)$ during March $16-20,2015$. During June 1-5, SSC-P and SSC-W decreased the average maximal root zone temperature by $1.28^{\circ} \mathrm{C}$ and $1.29^{\circ} \mathrm{C}$ compared to SR $\left(34.99^{\circ} \mathrm{C}\right)$, while PG increased it by $1.44^{\circ} \mathrm{C}$. PG, SSC-P, and SSC-W decreased the differences of average daytime and night time temperatures by $1.34^{\circ} \mathrm{C}, 2.13^{\circ} \mathrm{C}$, and $2.88^{\circ} \mathrm{C}$ compared to $\mathrm{SR}\left(4.56^{\circ} \mathrm{C}\right)$ during early stage. However, SSC-P and SSC-W decreased temperature differences of average daytime and night time by $0.9^{\circ} \mathrm{C}$ and $1.07^{\circ} \mathrm{C}$ compared to SR $\left(0.95^{\circ} \mathrm{C}\right)$ during later stage, but PG improved by $2.85^{\circ} \mathrm{C}$. Temperature difference of daytime and night time of SSC-W was minimal, and the temperature difference between the diurnal highest and the lowest temperature of SSC-W was also minimal. The buffer capacity of SSC-W was slightly better than that of SSC-P. SSC-W significantly improved the growth of sweet pepper compared to SR. Similarly, fruit yield per square meter of sweet pepper cultivated on SSC-P and SSC-W improved by $21.24 \%$ and $50.33 \%$, respectively compared to SR $\left(3.06 \mathrm{~kg} / \mathrm{m}^{2}\right)$, while PG lowered the yield by $13.72 \%$. SSC-W was a better SSC pattern compared with SSC-P in terms of production efficiency.
\end{abstract}

Keywords: soil cultivation, SSC, substrate cultivation, solar greenhouse, diurnal temperature difference, root zone temperature DOI: $10.25165 /$ j.jjabe.20181102.2679

Citation: Fu G H, Li Z G, Liu W K, Yang Q C. Improved root zone temperature buffer capacity enhancing sweet pepper yield via soil-ridged substrate-embedded cultivation in solar greenhouse. Int J Agric \& Biol Eng, 2018; 11(2): 41-47.

\section{Introduction}

Off-season fruit and vegetable production during winter and spring provides a significant economic advantage for vegetable growers due to high market price and huge consumption demand in China. During past decades, protected vegetable cultivation has rapidly developed in China due to its high profitability, and the area under cultivation has increased to 4 million hectares from less than 7.1 thousands hectares since $1978^{[1,2]}$. Nowadays, the area for protected vegetable cultivation in China (off-season production) accounted for more than $90 \%$ of the total cultivation area worldwide $^{[1]}$. Currently, Chinese protected horticultural facility types include plant factory, Chinese solar greenhouse (CSG), multi-span greenhouse, and plastic-covered tunnels. CSG is popular and dominant because it is easy to build at a low cost.

Received date: 2016-07-04 Accepted date: 2017-12-09

Biographies: Guohai Fu, Assistant Agronomist, research interests: popularizing agricultural technique, Email: fuguohai@agri.gov.cn; Zonggeng Li, Master, research interests: horticultural cultivation, Email: lizonggeng93@163.com; (These authors contributed equally to this study); Qichang Yang, Professor, research interests: environment control and greenhouse engineering. Email: yangqichang@caas.cn.

*Corresponding author: Wenke Liu, Professor, research interests: environment control and plant physiology of horticultural plants in controlled facilities. Institute of Environment and Sustainable Development in Agriculture, Chinese Academy of Agricultural Sciences, No.12 Zhongguancun South St., Haidian District, Beijing 100081, China. Tel: +86-10-82106015, Email: liuwenke@caas.cn.
Currently, CSG has become the native protected facility type, and occupied more than 1.0 million $\mathrm{hm}^{2}$ in North Chinese, Northwest Chinese, and Northeast Chinese regions ${ }^{[3]}$. CSG can meet the basic temperature requirements for fruit and vegetable growth. Currently, more than $90 \%$ of CSG are mainly used to cultivate off-season vegetables in China ${ }^{[4]}$.

However, a series of problems have occurred in CSG, which limit a sustainable protected fruit and vegetable production, such as soil continuous cropping obstacles ${ }^{[5]}$, soil salinization ${ }^{[6]}$, underground water pollution ${ }^{[7,8]}$, and high and low temperature stresses ${ }^{[9,10]}$. Temperature stresses are by far the most detrimental for a stable production. In CSG, the indoor temperature is passively elevated and lowered with changing outdoor temperature, and so high and low temperature stresses inevitably happen at some points during noon and at night. Temperature stress reduces crop yield by disturbing physiological processes in plants. Choi et al. ${ }^{[11]}$ demonstrated that the content of $\mathrm{H}_{2} \mathrm{PO}_{4}{ }^{-}$and $\mathrm{NO}_{3}{ }^{-}$in the xylem sap of cucumber at $12^{\circ} \mathrm{C}$ decreased compared to $22^{\circ} \mathrm{C}$, and the distribution of $\mathrm{H}_{2} \mathrm{PO}_{4}^{-}$and $\mathrm{NO}_{3}{ }^{-}$to the upper part of the plant were also reduced. High temperature could affect carbohydrate mobilization in plants by inhibiting enzyme synthesis such as that of the Rubisco protein ${ }^{[12,13]}$. Moreover, opening and closing of stomata are also affected by high temperature, and as a result, photosynthesis was ultimately affected ${ }^{[14-16]}$. Temperature stresses limit the adoption of CSG to continuously produce crops around the year, and the annual output of CSG is far lower than for a multi-span greenhous $\mathrm{e}^{[5,17]}$. Additionally, soil cultivation with excessive irrigation and fertilization destroys the ecological environment of 
soil. Therefore, long-term and extensive soil cultivation and poor temperature control are critical causes for these problems in CSG fruit and vegetable production.

Soilless cultivation is a popular method with high productivity in environmentally controlled facilities, e.g. multi-span greenhouses and plant factories. However, soilless cultivation cannot be directly adopted in CSG that are characterized by highly-changing temperature due to their inferior temperature buffer capacity of cultivation media (e.g. substrate or nutrient solution) compared to soils. In CSG, low and high temperature stresses in winter and summer are frequent and harmful. It has been reported that plant growth is more sensitive to root zone temperature than to air temperature ${ }^{[18]}$. Prasad et al. ${ }^{[19]}$ demonstrated that high air temperature had no significant effect on total flower production of groundnuts; however, high root zone temperature significantly reduced flower production. Moreover, Schwarz et al. indicated that net photosynthesis was more sensitive to the changes in soil temperature than to the changes in canopy air temperature ${ }^{[20]}$. Furthermore, He and Lee indicated that the photosynthetic rate and productivity of lettuce whole plants cultured under high ambient temperatures decreased by more than $50 \%$ compared to when cultured under a low root zone temperature of $20^{\circ} \mathrm{C}^{[14,15]}$. Low or high root zone temperatures would become an adverse factor and induce negative effects on root physiology and plant growth even if air temperature was suitable for photosynthesis ${ }^{[21,22]}$. Moreover, nutrient uptake and root growth were inhibited by high and low root zone temperatures ${ }^{[23,24]}$. Furthermore, high and low root zone temperatures affect growth, gas exchange, photosynthesis, and survival following transplanting ${ }^{[25]}$. Since root zone temperature regulation is important for vegetable health and production ${ }^{[16]}$, improving the root zone temperature buffer capacity is a vital topic that needs to be solved for all soilless cultivation methods prior to the practical application in CSG.

To overcome the problems of vegetable production in CSG, the novel semi-soilless cultivation pattern soil-ridged substrateembedded cultivation (SSC) was invented to replace traditional soil cultivation in CSG. The structure of the SSC pattern looks like a vertically arranged "sandwich" structure. A U-shape groove full of substrate was inserted in the middle, and the lateral side was covered by soil to form a cultivation ridge. Finally, the SSC ridge was covered with plastic film. SSC can make full use of both high productivity performance of soilless cultivation ${ }^{[26]}$ and of root zone temperature buffer capacity of soil cultivation. Thus, SSC ridges may present improved diurnal root zone temperature under plastic film mulching compared to soil cultivation ridges ${ }^{[27]}$. The present study was designed to investigate the feasibility of SSC application in CSG fruit and vegetable production and to evaluate the effects of SSC patterns on the changes of root zone temperature, growth, and fruit yield of sweet pepper.

\section{Materials and methods}

\subsection{Experimental materials}

The experiment was conducted in a CSG located at the Institute of Environment and Sustainable Development in Agriculture, Chinese Academy of Agricultural Sciences in Dasungezhuang town, Shunyi District, Beijing during the $10^{\text {th }}$ of March to the $20^{\text {th }}$ of June, 2015. The length, width, and height of CSG was $60 \mathrm{~m}, 8 \mathrm{~m}$ and $3.8 \mathrm{~m}$, respectively, and the dimensions of the experimental plot were $15 \mathrm{~m}$ length, $5 \mathrm{~m}$ width, and $1.5 \mathrm{~m}$ distance from the southern tip of the CSG. The sweet pepper cultivar (Capsicum annuum L. Haifeng No.16) was used as plant material. Seeds were germinated in trays that were filled with vermiculite, and were watered once per day. On $20^{\text {th }}$ of March 2015, uniform seedlings with three complete leaves, were transplanted on ridges, $30 \mathrm{~cm}$ apart. Indoor temperature of CSG ranged between $10^{\circ} \mathrm{C}$ and $25^{\circ} \mathrm{C}$ during the period of seedling growth, and sweet pepper was under low temperature stress in the evening, despite a heat-preservation cover being used to increase heat during the night. After May, sweet pepper plants were under high temperature stress during the day in the fruiting and mature stage of sweet pepper with a CSG outdoor temperature range of $25^{\circ} \mathrm{C}-40^{\circ} \mathrm{C}$. The heat preservation quilt was not used.

\subsection{Experimental design}

Four treatments were conducted, including traditional soil ridge (SR) cultivation, bare substrate cultivation via polyethylene groove filled with substrate (PG) and two patterns of SSC. SR specification was identical to the normal SSC ridge, and the PG specification identical to the normal groove of SSC (Figure 1). In this study, two types of SSC patterns were designed by embedding a polyethylene groove (PE groove, SSC-P) and wire-mesh groove plus plastic film (SSC-W) filled with substrate in a special soil ridges. The following steps were used to construct SSC ridges. Firstly, specially made grooves with inserted plastic film full of substrate were trimly placed on the ground along the north-south direction, and then they were filled with substrate, which was equally mixed parts of peat, vermiculite, and perlite at the same volume ratio $(1: 1: 1)$. Moreover, soil was collected and piled along both sides of the ridges of the special groove to increase compactness. Lastly, the SSC ridge was covered by plastic mulch, and drip irrigation was used to supply water and fertilizer via nutrient solution. Figure 1 shows that a whole SSC ridge was comprised of soil, groove, inserted plastic film, substrate, covered plastic mulch, and drip irrigation system; thus, soil cultivation and soilless cultivation were tightly integrated. In addition, $2 \mathrm{~mm}$ wall thickness PE groove was used for PG and SSC-P, while wire-mesh plus plastic film groove was used for SSC-W. The specification of the U-shape groove was $120 \mathrm{~cm}$ length, $12 \mathrm{~cm}$ width, and $16 \mathrm{~cm}$ height. Grooves were punched laterally, with a distance from the bottom of $5 \mathrm{~cm}$, and holes $(1 \mathrm{~cm}$ diameter) were cross-wise ranked into two rows with $5 \mathrm{~cm}$ lateral distance and $2.5 \mathrm{~cm}$ longitudinal distance. Both types of SSC patterns were constructed with the same approach. Then, white plastic film $(0.06 \mathrm{~mm}$ thick $)$ was used to cover both types of SSC pattern ridges and a drip irrigation system was synchronously set up. The distance of ridges $(42 \mathrm{~cm}$ bottom width, $22 \mathrm{~cm}$ top width, and $15 \mathrm{~cm}$ height) was $67 \mathrm{~cm}$, which was articulated due to the necessity of production.

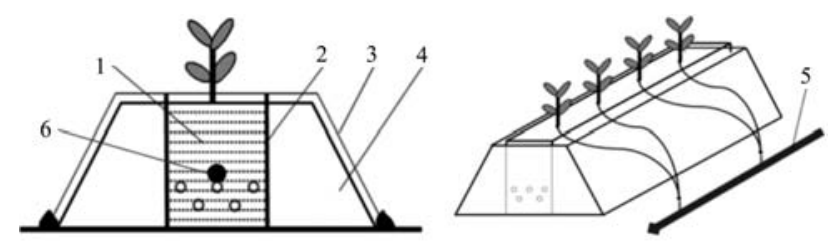

1. Substrate 2. PE groove or wire-mesh plus plastic film 3. Plastic mulch 4. Soil 5. Drip irrigation tube 6. Measurement site of root zone temperature

Figure 1 Cross section (left) and aerial view (right) of a novel soil ridge substrate-embedded cultivation method for CSG

All treatments were carried out with three replicates, e.g. three rows were arranged in east to west direction. Apart from twelve experimental ridges, two guard rows were set up at the eastern and western border of the experimental plot. Ridge length in north to south direction was kept at $2.4 \mathrm{~m}$, and light and temperature across the experimental plot were almost the same. Fourteen different temperature measurement sites were utilized. Two measurement 
sites, which were protected from light by covering them with aluminized paper, were used to measure indoor and outdoor aerial temperature of CSG, and the indoor and outdoor temperature measurement sites were all $2 \mathrm{~m}$ above the ground. Moreover, root zone temperature measurement sites were placed into the center of ridges (center site), $10 \mathrm{~cm}$ below the ridge from the top surface of $\mathrm{SR}$, PG, SSC-P, and SSC-W (Figure 1). After all treatments had been established, a drip irrigation system was put in. Then, seedlings (15 d after emergence) were automatically watered with nutrient solution $(\mathrm{EC}=1.2 \mathrm{~ms} / \mathrm{cm}, \mathrm{pH} 6.0)$ at $8: 30$ and $14: 30$ during the period of seedlings, respectively, and the irrigation volume of every seedling was $50 \mathrm{ml}$ at a time. At the flowering stage, sweet peppers were watered with nutrient solution $(\mathrm{EC}=1.5 \mathrm{~ms} / \mathrm{cm}, \mathrm{pH} 6.0)$ at $8: 30$, 12:00, and 14:30, respectively, and the irrigation volume per plant was $80 \mathrm{ml}$ at a time. At the fruiting stage, sweet pepper plants were watered with nutrient solution $(\mathrm{EC}=1.5 \mathrm{~ms} / \mathrm{cm}, \mathrm{pH} 6.0)$ at $8: 30$, $12: 00$, and 14:30, respectively, and the irrigation volume of every plant was $100 \mathrm{~mL}$ at a time. The irrigation quantity was adjusted in accordance with seedling growth. Finally, data measurement was started after the cultivation system was finished.

\subsection{Methods of measurement and harvest}

Indoor temperature, outdoor temperature, and root zone temperature were recorded every $20 \mathrm{~min}$ by an Intelligent System of Temperature and Humidity Sampling for Soil (YM-CJ, $\pm 0.05^{\circ} \mathrm{C}$, Handan Yimeng Electronics Co. Ltd., China), and root zone temperatures of SR, PG, SSC-P, and SSC-W patterns were recorded at seedling stage during $16^{\text {th }}$ to $20^{\text {th }}$ of March 2015 and at fruiting stage during $1^{\text {st }}$ to $5^{\text {th }}$ of June, respectively. Ripe sweet pepper fruits were harvested on $10^{\text {th }}$ of June 2015 ( $80 \mathrm{~d}$ after transplanting)

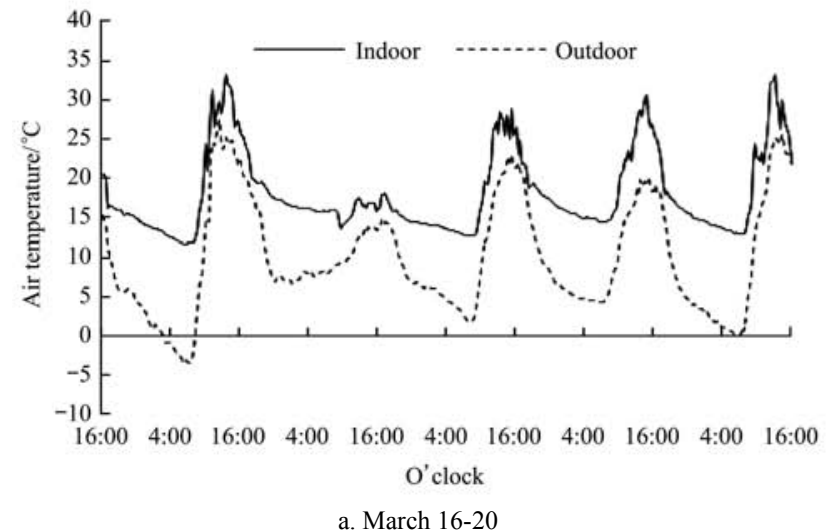

and on $17^{\text {th }}$ of June 2015. Fruit weight and size were measured via platform and vernier caliper $80 \mathrm{~d}$ after transplanting, and mean values of three matured fruits per plant were obtained. The stem diameter was measured $80 \mathrm{~d}$ after transplanting via vernier caliper. Leaf chlorophyll contents and plant height were measured $25 \mathrm{~d}, 50 \mathrm{~d}$, and $80 \mathrm{~d}$ after transplanting via chlorophyll meter (SPAD-502, Konica Minolta Sensing Inc., Osaka, Japan) and ruler, respectively. The plant fresh and dry weights were measured via weighing scales after harvest.

\subsection{Statistical analyses}

Analyzed data included the mean values of five plants that were randomly chosen from every treatment. Statistical analyses were performed with software packages Excel 2003 and SAS 8.2, analyzing the root zone temperature, the difference in plant height, leaf chlorophyll content, stem diameter, fruit weight, and fruit size of sweet pepper cultivated on four cultivation patterns. The level of $p<0.05$ based on Duncan's multiple range test was used to evaluate significance.

\section{Results}

\subsection{Indoor and outdoor temperatures of CSG and root zone temperatures of four cultivation patterns}

From $16^{\text {th }}$ to $20^{\text {th }}$ of March 2015, the indoor temperature changed from $11.70^{\circ} \mathrm{C}$ to $33.30^{\circ} \mathrm{C}$, and the average minimal and average maximal indoor temperatures were $13.48^{\circ} \mathrm{C}$ and $28.60^{\circ} \mathrm{C}$ (Figure 2a). During $1^{\text {st }}$ to $5^{\text {th }}$ of June, results showed that the indoor temperature ranged from $18.87^{\circ} \mathrm{C}$ to $43.34^{\circ} \mathrm{C}$, and the average minimal and maximal indoor temperatures were $23.77^{\circ} \mathrm{C}$ and $37.79^{\circ} \mathrm{C}$ (Figure 2b).

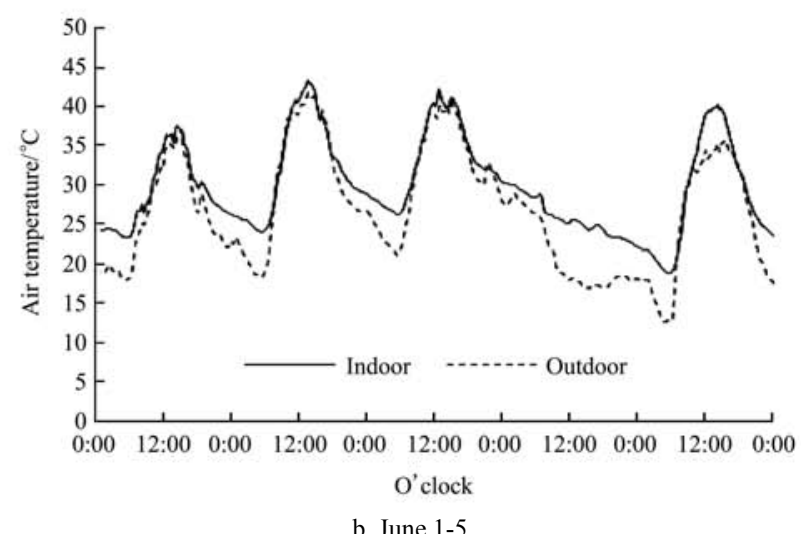

Figure 2 Indoor and outdoor temperature changes of CSG

From $16^{\text {th }}$ to $20^{\text {th }}$ of March (Figure 3a), the average minimal root zone temperatures of $\mathrm{PG}, \mathrm{SSC}-\mathrm{P}$, and SSC-W were $17.34^{\circ} \mathrm{C}$, $17.08^{\circ} \mathrm{C}$, and $17.49^{\circ} \mathrm{C}$. PG, SSC-P, and SSC-W improved the average minimal root zone temperature by $1.01^{\circ} \mathrm{C}, 0.75^{\circ} \mathrm{C}$, and $1.16^{\circ} \mathrm{C}$ compared to $\mathrm{SR}\left(16.33^{\circ} \mathrm{C}\right)$, respectively. The average maximal root zone temperatures of PG, SSC-P, and SSC-W were $27.21^{\circ} \mathrm{C}, 25.19^{\circ} \mathrm{C}$, and $24.64^{\circ} \mathrm{C}$, and SSC-P and SSC-W decreased the average maximal root zone temperature by $0.58^{\circ} \mathrm{C}$ and $1.13^{\circ} \mathrm{C}$ compared to $\mathrm{SR}\left(25.77^{\circ} \mathrm{C}\right)$, while PG improved by $1.44^{\circ} \mathrm{C}$. During $1^{\text {st }}$ and $5^{\text {th }}$ of June (Figure $3 \mathrm{~b}$ ), the average maximal root zone temperatures of $\mathrm{PG}$, SSC-P, and SSC-W were $36.43^{\circ} \mathrm{C}$, $33.71{ }^{\circ} \mathrm{C}$, and $33.70^{\circ} \mathrm{C}$, respectively. SSC-P and SSC-W decreased the average maximal root zone temperature by $1.28^{\circ} \mathrm{C}$ and $1.29^{\circ} \mathrm{C}$ compared to SR $\left(34.99{ }^{\circ} \mathrm{C}\right)$, respectively, while PG improved by $1.44^{\circ} \mathrm{C}$ compared to SR. PG, SSC-P, and SSC-W improved the average minimal root zone temperature by $0.93^{\circ} \mathrm{C}$ and $1.20^{\circ} \mathrm{C}$ compared to SR $\left(24.63^{\circ} \mathrm{C}\right)$, while PG decreased $1.04^{\circ} \mathrm{C}$.

From $16^{\text {th }}$ to $20^{\text {th }}$ of March, PG, SSC-P, and SSC-W decreased the average differences of daytime and night time temperatures by $1.34^{\circ} \mathrm{C}, 2.13^{\circ} \mathrm{C}$, and $2.88^{\circ} \mathrm{C}$ compared to SR $\left(4.56^{\circ} \mathrm{C}\right)$, respectively (Figure 4a). During $1^{\text {st }}$ and $5^{\text {th }}$ of June, SSC-P and SSC-W decreased temperature differences of daytime and night time by $0.9^{\circ} \mathrm{C}$ and $1.07^{\circ} \mathrm{C}$ compared to $\mathrm{SR}\left(0.95^{\circ} \mathrm{C}\right)$, respectively, while PG improved temperatures by $2.85^{\circ} \mathrm{C}$ compared to SR (Figure $4 \mathrm{~b}$ ).

Figure 5a showed that the temperature differences between the highest and the lowest temperatures of SSC-P and SSC-W were $1.33^{\circ} \mathrm{C}$ and $2.29^{\circ} \mathrm{C}$ lower than those of SR $\left(9.44^{\circ} \mathrm{C}\right)$, respectively, while that of $\mathrm{PG}$ was $0.43^{\circ} \mathrm{C}$ higher than SR. Figure $5 \mathrm{~b}$ showed that the temperature differences between the highest and the lowest temperatures of SSC-P and SSC-W were $2.20^{\circ} \mathrm{C}$ and $2.49^{\circ} \mathrm{C}$ lower than for SR $\left(10.36^{\circ} \mathrm{C}\right)$, respectively, while $\mathrm{PG}$ was $2.48^{\circ} \mathrm{C}$ higher than SR. These results indicated that the SSC method remarkably 
improved the buffer capacity of root zone temperature both in low and high ambient temperature environments, and the root zone

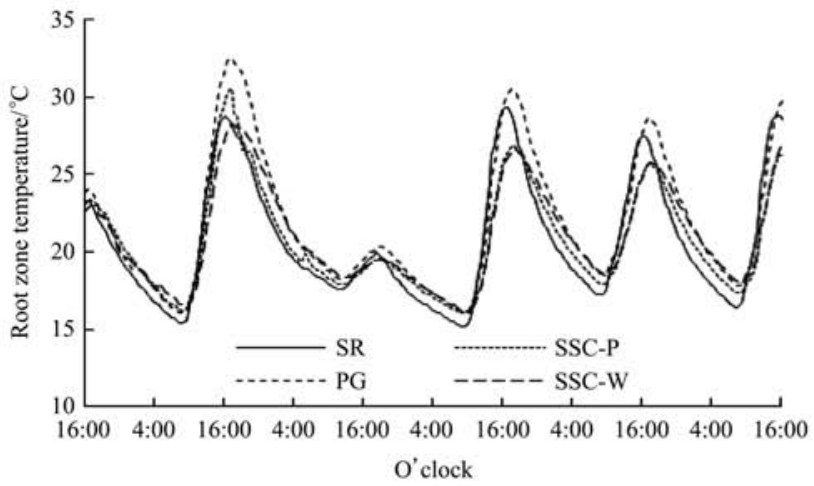

a. March 16-20 temperature buffer capacity of SSC-W was slightly better than that of SSC-P.

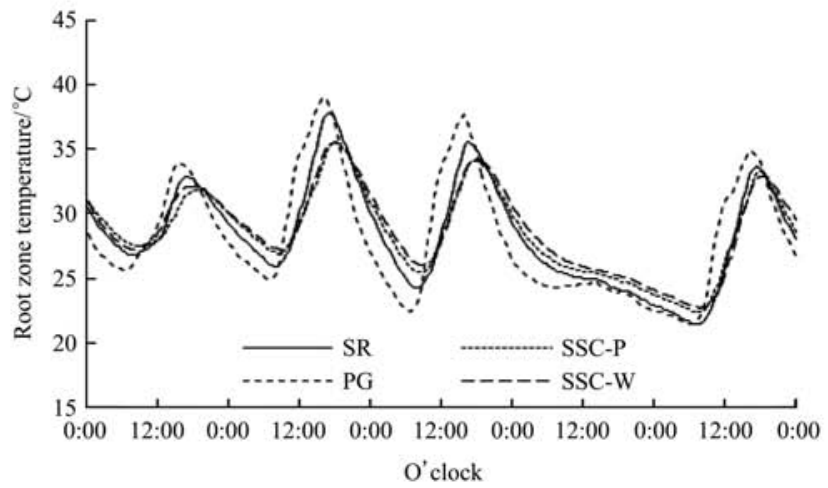

b. June 1-5

Figure 3 Root zone temperature changes of four cultivation patterns

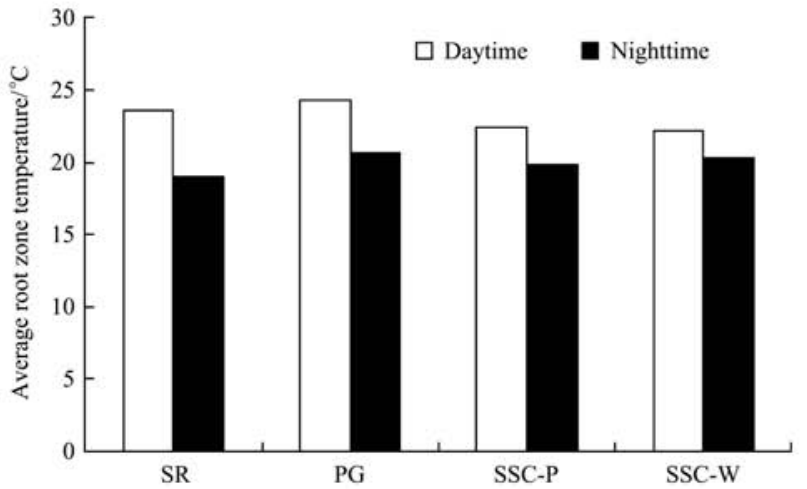

a. March 16-20

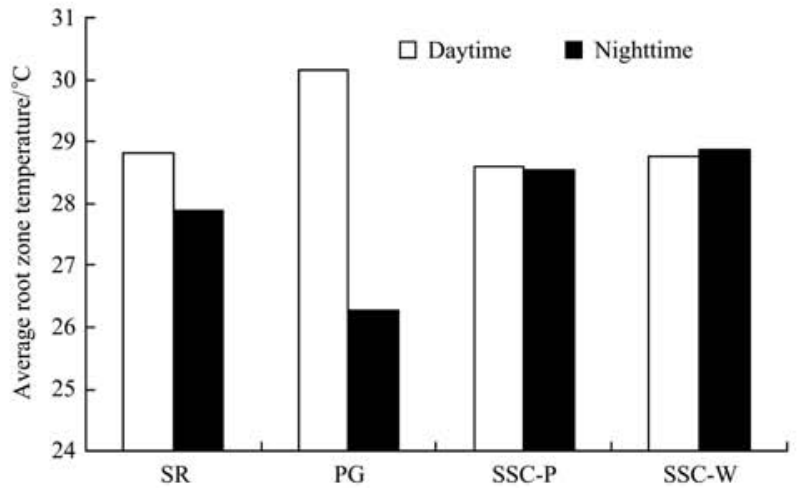

b. June $1-5$

Figure 4 Average root zone temperatures in daytime and night time of four cultivation patterns
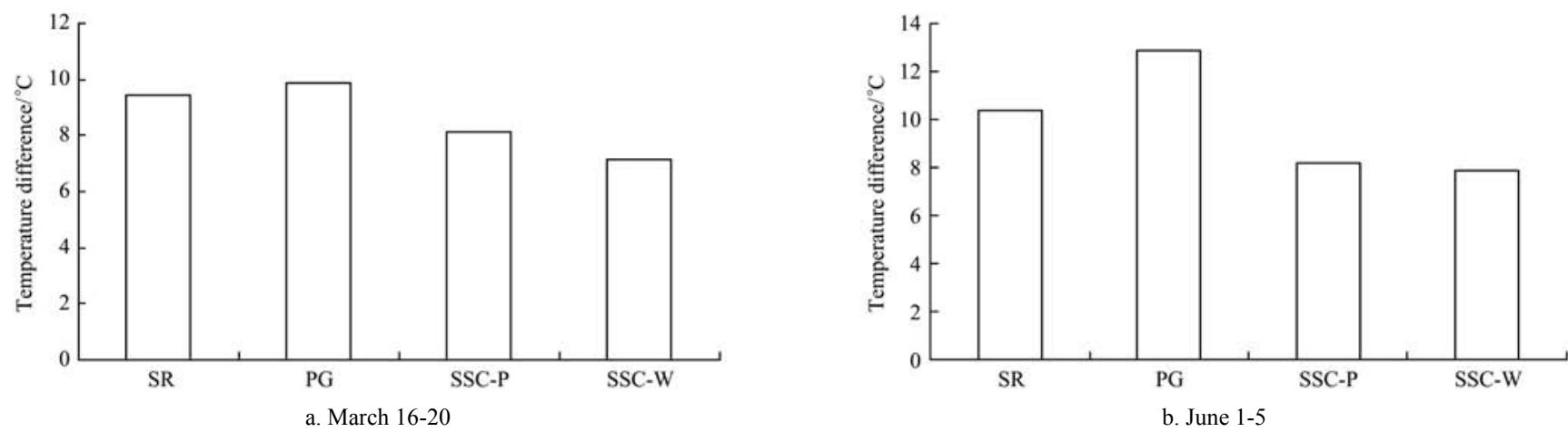

Figure 5 Temperature differences of average the highest and the lowest temperature of root zone

3.2 Effects of four cultivation patterns on sweet pepper morphological and physiological parameters

Table 1 showed that stem diameter, dry and fresh shoot weight, and dry root weight of sweet peppers cultivated on SSC-P and SSS-W were not significantly different compared to SR, and values for PG were lower compared to those of SR. Growth of sweet pepper cultivated on PG was limited compared to the other three treatments. Otherwise, the fresh root weight of sweet pepper cultivated on PG, SSC-P, and SSC-W were higher than those of SR, and differences of SSC-P and SSC-W were not significant. Plant height of four treatments decreased in the following order: SSC-W, SSC-P, SR, PG.

Table 1 Morphology of sweet pepper cultivated on four cultivation patterns at harvest

\begin{tabular}{|c|c|c|c|c|c|c|}
\hline Treatments & Stem diameter $/ \mathrm{mm}$ & Plant height $/ \mathrm{cm}$ & Fresh shoot weight/g & Dry shoot weight/g & Fresh root weight/g & Dry root weight/g \\
\hline SR & $12.37 \mathrm{a}$ & $63.25 \mathrm{ab}$ & $288.33 \mathrm{a}$ & $51.53 \mathrm{a}$ & $34.00 \mathrm{~b}$ & $8.74 \mathrm{a}$ \\
\hline PG & $11.00 \mathrm{~b}$ & $48.00 \mathrm{c}$ & $136.25 b$ & $21.79 \mathrm{~b}$ & $42.85 \mathrm{ab}$ & $5.69 b$ \\
\hline SSC-P & $12.29 \mathrm{a}$ & $60.25 b$ & $242.50 \mathrm{a}$ & $41.60 \mathrm{a}$ & $46.78 \mathrm{a}$ & $8.78 \mathrm{a}$ \\
\hline SSC-W & $13.63 \mathrm{a}$ & $64.75 \mathrm{a}$ & $273.75 \mathrm{a}$ & $42.96 \mathrm{a}$ & $45.76 \mathrm{a}$ & $8.39 \mathrm{a}$ \\
\hline
\end{tabular}

Note: Mean values $(n=5)$ followed by different letters within a column indicated significant differences at $p<0.05$ based on Duncan's multiple range test. 
Figure 6a showed similar growth rates of sweet pepper cultivated on PG, SSC-P, and SSC-W within $50 \mathrm{~d}$ after transplanting. However, the growth rate of sweet pepper cultivated on SR was quickly accelerated with increasing plant height $50 \mathrm{~d}$ later; however, that of PG lagged behind. Figure $6 \mathrm{~b}$ shows that the leaf chlorophyll content of sweet pepper cultivated on SR, SSC-P, and SSC-W remained identical, but the leaf chlorophyll content of sweet pepper

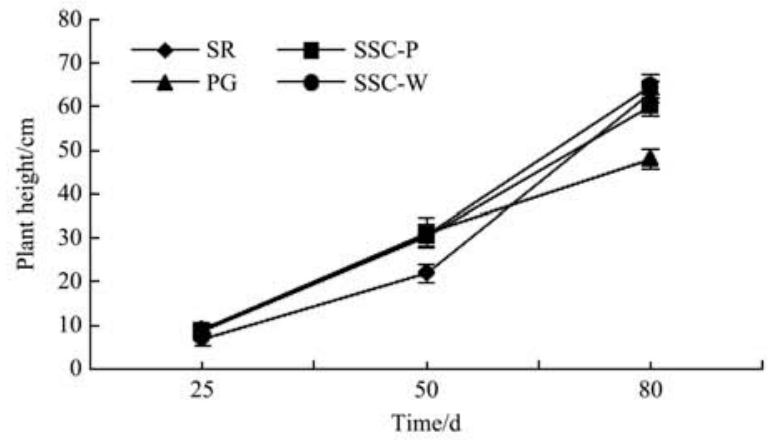

cultivated on PG was lower than for others, and the changes were not obvious in low and high temperature stages.

Figure 7 showed that the leaf green colour of PG was lighter than that of other treatments, while the green colour of leaves of other treatments were similar. Furthermore, the canopy sizes of PG, SSC-P, and SSC-W were larger than that of SR.

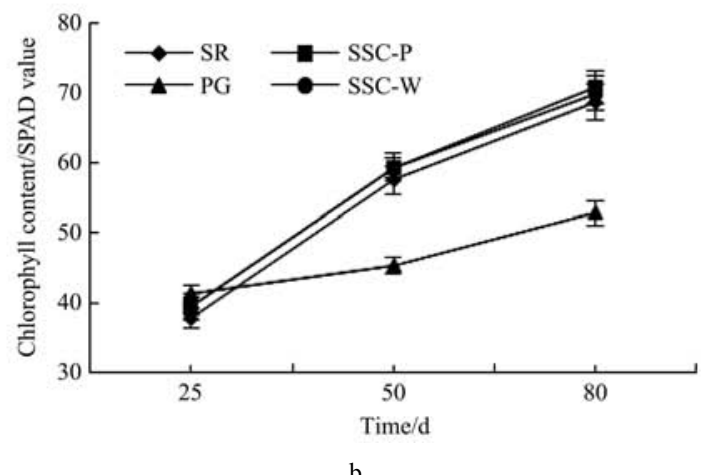

b

Figure 6 Effects of four cultivation patterns on height (a) and leaf chlorophyll content (b) of sweet pepper in three growth stages

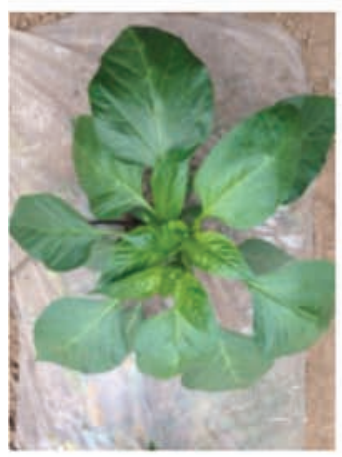

a

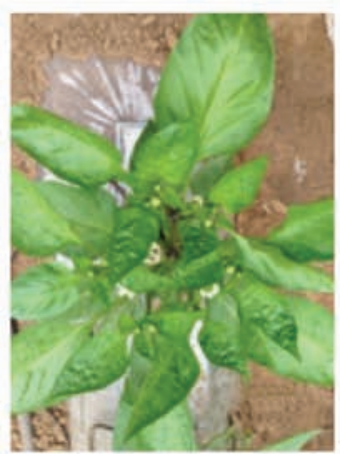

$\mathrm{b}$

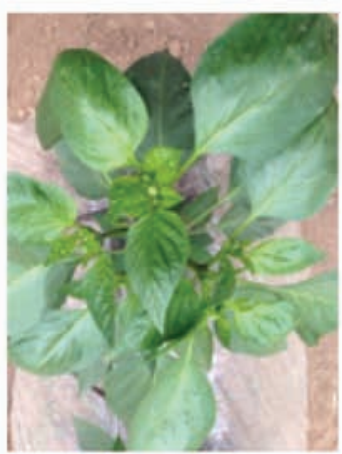

c

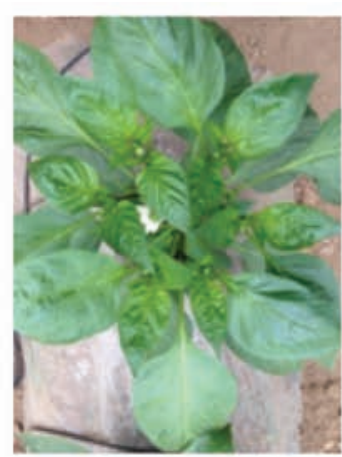

d

Note: Picture (a) to picture (d) are canopies of sweet pepper seedlings cultivated on SR, PG, SSC-P and SSC-W, respectively.

Figure 7 Canopy of sweet pepper seedlings cultivated on four types of patterns $50 \mathrm{~d}$ after transplanting

3.3 Effects of four cultivation patterns on sweet pepper fruit quality and yield

Cultivation methods significantly affected fruit quality and yield of sweet pepper (Table 2). Fruit diameter, length, single fruit weight, and single plant yield of sweet pepper cultivated on SSC-W were higher than those on SR, PG, and SSC-P, while yield on SSC-P slightly improved fruit length compared to yield on SR and PG. Per unit area of sweet pepper fruit yield cultivated on SSC-P and SSC-W were $21.24 \%$ and $50.33 \%$ higher than that of SR $\left(3.06 \mathrm{~kg} / \mathrm{m}^{2}\right)$. And SSC-P and SSC-W achieved $40.53 \%$ and $74.24 \%$ higher per unit area of sweet pepper fruit yield compared to PG. The per unit area fruit yield of sweet pepper decreased in the following order: SSC-W, SSC-P, SR, PG, suggesting that the yield of soilless cultivation was higher than soil but lower in case of PG.

Table 2 Fruit quality and yield of sweet pepper cultivated on four cultivation patterns

\begin{tabular}{|c|c|c|c|c|c|}
\hline Treatments & Fruit diameter $/ \mathrm{cm}$ & Fruit length/cm & Single fruit weight $/ \mathrm{g}$ & Single plant yield/kg per plant & Yield $/ \mathrm{kg} \cdot \mathrm{m}^{-2}$ \\
\hline SR & $8.11 \mathrm{~b}$ & $5.50 \mathrm{~b}$ & $95.08 \mathrm{~b}$ & $0.62 b$ & 3.06 \\
\hline PG & $8.34 b$ & $5.60 \mathrm{~b}$ & $96.25 b$ & $0.45 b$ & 2.64 \\
\hline SSC-P & $8.42 b$ & $6.18 \mathrm{ab}$ & $118.54 b$ & $0.73 b$ & 3.71 \\
\hline SSC-W & $9.92 \mathrm{a}$ & $6.68 \mathrm{a}$ & $155.42 \mathrm{a}$ & $1.02 \mathrm{a}$ & 4.60 \\
\hline
\end{tabular}

Note: Mean values $(n=5)$ followed by different letters within a column indicated significant differences at $p<0.05$ based on Duncan's multiple range test.

\section{Discussion}

SSC is a novel soil-substrate compound cultivation method, i.e. a semi-soilless cultivation method, with significant practical advantages that allow solving arising problems in fruit and vegetable production in CSG. The results showed that SSC-P and SSC-W could effectively buffer extreme low and high root zone temperatures compared to SR and PG. When the indoor air temperature was low, the root zone temperature of SR was relatively low; however, when the air temperature was high, $\mathrm{PG}$ had a relative high root zone temperature compared to SSC treatments. Both SR and PG have inferior buffer capacity of root zone temperature under sharply fluctuant air temperatures compared to SSC patterns. SSC-P and SSC-W improved average minimal root temperature by $0.75^{\circ} \mathrm{C}$ and $1.16^{\circ} \mathrm{C}$ compared to SR $\left(16.33^{\circ} \mathrm{C}\right)$ during $16^{\text {th }}$ and $20^{\text {th }}$ of March; moreover, SSC-P and SSC-W decreased root zone temperatures by $2.71^{\circ} \mathrm{C}$ and $2.73^{\circ} \mathrm{C}$ compared to $\mathrm{PG}\left(36.43^{\circ} \mathrm{C}\right)$ during $1^{\text {st }}$ and $5^{\text {th }}$ of June. In production, root zone temperature of 
sweet pepper at the seedling stage is more suitable about $18^{\circ} \mathrm{C}$, and the root zone temperature should be around $30^{\circ} \mathrm{C}$ in fruit ripening period. SSC-P and SSC-W could effectively reduce low and high temperature stress. Moreover, SSC-P and SSC-P had less difference of low and high temperature between average daytime and nighttime temperature, and on average the highest and the lowest diurnal temperature. This data revealed that soil plus substrate could store more heat in a low temperature environment to maintain root zone temperature compared to soil only, while it prevented sudden increase of root zone temperature at daytime under high temperature environment compared to single substrate. SSC could be used in CSG which has a poor buffer capacity of air temperature that suffered from outdoor temperature diurnal change. Moreover, the root zone temperature buffer capacity of SSC-W was slightly better than that of SSC-P. Therefore, SSC-W has the advantage of buffering root zone temperature at relatively moderate range, which is beneficial for crop growth since it eliminates extreme temperature stresses to some extent. This study confirmed that the root zone temperatures of SSC-P and SSC-W were higher compared to SR during $16^{\text {th }}$ and $20^{\text {th }}$ of March, while they were lower compared to PG during $1^{\text {st }}$ and $5^{\text {th }}$ of June due to the combination of soil and substrate. The root zone temperatures of all treatments increased with absorbing solar radiation during the daytime $^{[28]}$. Heat absorbed by lateral soil of SSC ridge daytime could be transmitted to the root zone at night, which would increase the root zone temperature. The difference in heat absorption and different traits between soil and substrate could be attributed to this. Moreover, the root zone temperature of SSC increased slower as a result of the significant buffer effect of lateral soil under high ambient temperature compared to PG, which lacked of the outside soil buffer. The change of temperature was related to the composition and state of material ${ }^{[29]}$, and root zone temperature was not stable since the structural stability of the substrate was not stable. In contrast, soil can provide a more stable root zone temperature for plant roots ${ }^{[10]}$. Consistently, SR was only made of soil, while PG was composed of polyethylene groove and substrate. Therefore, the heat, which was absorbed by lateral soil of SR could not efficiently transmit to the far root zone due to the dense texture of soil; thus, the temperature of the root zone could not be effectively improved. Meanwhile, the root zone temperature of PG rapidly increased in a high temperature environment due to a high rate of heat transfer in the substrate. Remarkably, the root zone temperature of SSC-W was higher than that of SSC-P in a low temperature environment, which may be due to negative impact of the PE substrate groove on the conduction of heat. With good heat storage capacity and buffer effect of SSC-W, an optimal cultivation pattern could be selected to replace conventional soil cultivation.

Compared to SR, PG, and SSC-P, SSC-W improved the growth and fruit yield of sweet pepper. Per unit fruit yield of sweet pepper cultivated on SSC-W was higher by $50.33 \%$ compared to that of SR $\left(3.06 \mathrm{~kg} / \mathrm{m}^{2}\right)$, while PG was $13.72 \%$ lower than SR. Moreover, per unit area of sweet pepper fruit yield cultivated on SSC-W was $74.24 \%$ higher than PG $\left(2.64 \mathrm{~kg} / \mathrm{m}^{2}\right)$. It suggested that SSC-W with both the advantages of soilless cultivation and strong root zone temperature buffer capacity could improve the yield of sweet pepper. Therefore, SSC-W is a novel promising semi-soilless cultivation patterns to increase sweet pepper fruit yield in CSG with the advantages of enhancing strong ability of root zone temperature buffer capacity with the aid of ridge lateral soil. Currently, SSC-W is much more practical due to low price and recycling ability. PG without soil covering could not buffer the high root zone temperature, and consequently inhibited the growth and fruit yield of sweet pepper compared to other treatments due to high root zone temperature ${ }^{[30,31]}$. Previous studies showed that the effects of high root zone temperature on plants were more apparent than those of high air temperature ${ }^{[18,32]}$. For example, a high root zone temperature reduced the accumulation of dry matter and affected the growth of sweet pepper ${ }^{[33]}$. Moreover, SR limited the growth of sweet pepper due to low temperature stress; however, the growth was promoted with increasing root zone temperature. PG limited the growth of sweet pepper in the later stage because the root zone could not be buffered under high ambient temperature. The fruit yield of soilless cultivation was higher than that of soil cultivation due to high utilization efficiencies of water and fertilizer ${ }^{[30,34]}$; however, PG could not promote the yield due to its poor root zone temperature buffer capacity.

At present, the buffer capacity of CSG temperature is poor due to the rough structure and the lack of environmental control equipment. Soilless cultivation was first successfully introduced into CSG fruit and vegetable production by establishing a SSC practical method, which has strong buffer capacity of root zone temperature. The SSC method has the potential to replace the traditional soil cultivation in China in future to solve some environmental and production problems. SSC is promising to achieve high fruit yield due to its soilless cultivation traits. Furthermore, SSC presented high use efficiency of water and mineral nutrients due to closed groove bottom without fertilizer and water infiltration. It prevented nitrate and phosphate leaching into the soil, thus avoiding soil and groundwater contamination ${ }^{[35,36]}$. Additionally, the substrate and grooves of SSC can be reused after treatment. SSC can reduce labour intensity compared to pure soil ridge without heavy soil disturbance. More importantly, it is suggested that some pathogenic bacteria cannot survive because soil was heated under film and isolated from roots. And another crucial benefit is offered by lateral soil coverage, i.e., root zone temperature buffer capacity in low ambient temperatures. Although the production cost has increased, farmers can gain more benefit due to high yield.

\section{Conclusions}

1) Two SSC experimental patterns, i.e. SSC-P (polyethylene groove inserted) and SSC-W (wire-mesh groove inserted) showed better root zone temperature buffer capacity during two stages. SSC-P and SSC-W increased the average minimal root zone temperature by $0.75^{\circ} \mathrm{C}$ and $1.16^{\circ} \mathrm{C}$ compared to SR during March, 2015. SSC-P and SSC-W decreased root zone temperatures by $2.71^{\circ} \mathrm{C}$ and $2.73^{\circ} \mathrm{C}$ compared to PG during $1^{\text {st }}$ and $5^{\text {th }}$ of June. Moreover, the temperature difference of daytime and nighttime of SSC-W was minimal, and the temperature difference between the diurnal highest and the lowest temperature of SSC-W was also minimal. The buffer capacity of SSC-W was slightly better than that of SSC-P.

2) SSC-W and SSC-P improved growth and fruit yield of sweet pepper significantly compared to SR. Fruit yield per square meter of sweet pepper cultivated on SSC-P and SSC-W improved by $21.24 \%$ and $50.33 \%$ compared to SR $\left(3.06 \mathrm{~kg} / \mathrm{m}^{2}\right)$, while PG lowered the yield by $13.72 \%$. Moreover, per unit area of sweet pepper fruit yield cultivated on SSC-P and SSC-W were $40.53 \%$ and $74.24 \%$ higher than PG $\left(2.64 \mathrm{~kg} / \mathrm{m}^{2}\right)$. SSC-W was a better SSC pattern compared with SSC-P in terms of production efficiency.

3) Improved productivity of sweet pepper cultivated by SSC method may attribute to its ability to enhance root zone temperature 
buffer capacity and soilless cultivation. SSC is a feasible substrate cultivation method to replace soil cultivation and single soilless cultivation for fruit and vegetable production in Chinese solar greenhouse (CSG) suffering to temperature stress and soil cultivation problems. In addition, the increase in investment does not reduce the income of farmers due to high yield.

\section{Acknowledgement}

This research was financially supported by the National Key Research and Development Project of China (Grant No.2016YFD0801001), the National High Technology Research and Development Program (863 Program, Grant No. 2013AA103001) and the Basic Scientific Research Fund of National Nonprofit Institutes.

\section{[References]}

[1] Guo S R, Shu J, Shu S, Lu X M, Tian J, Wang J W. Analysis of general situation, characteristics, existing problems and development trend of protected horticulture in China. China Vegetables, 2012; 18: 1-14.

[2] Li T L. Theory and practice on vegetable cultivation in solar greenhouse. Beijing: China Agricultural Press, 2014.

[3] Wei X M, Zhou C J, Cao N. Evolution of structure and performance of Chinese solar greenhouse. Jiangsu Academy Agricultural Sciences, 2012; 28: 855-860.

[4] Jiang W J, Deng J, Yu H J. Development Situation, Problems and Suggestions on Industrial Development of Protected Horticulture. Scientia Agricultura Sinica, 2015; 48: 3515-3523.

[5] Guo S R, Sun J, Shu S, Li J. General situations, charactics and trends of protected horticulture in foreigns. Journal of Nanjing Agricultural University, 2012; 35: 43-52.

[6] He Y, Yang J, Zhu B, Zhu Z J. Low root zone temperature exacerbates the ion imbalance and photosynthesis inhibition and induces antioxidant responses in tomato plants under salinity. Journal of Integrative Agriculture, 2014; 13: 89-99.

[7] Wang Y Q, Peng Z P, Xue S C, Yang Y M, Zhou Y P, Zhao L B. Effect of excessive fertilization on soil ecological environment in the facility farmland. Journal of Agro-Environment Science, 2005; 24: 81-84.

[8] Peng N, Wang K F, Xie X L, Hu S. Effects of different utilization model on soil water redistributions, runoff and nutrition loss on red sloping lands. Research of Soil and Water Conservation, 2008; 15: 53-56.

[9] Chen D S. Theory and practice of energy saving solar greenhouse in China. Transactions of the CSAE, 2001; 17: 22-26.

[10] Ren Z Y, Wang X F, Wei M, Yu W H. Effects of different root zone temperature on growth and photosynthetic parameters of cucumber seedlings. Journal of Shandong Agricultural University, 2003; 34: 64-67.

[11] Choi K J, Chung G C, Ahn S J. Effect of root zone temperature on the mineral composition of xylem sap and plasma membrane $\mathrm{K}^{+}-\mathrm{Mg}^{2+}$-ATPase activity of grafted-cucumber and -fig leaf gourd root systems. Plant Cell Physiology, 1995; 36: 639-643.

[12] Liu J M, Zhao Q, Yin Z P, Xu C X, Wang Q H, Dai S J. Heat-responsive mechanisms in plants revealed by proteomic analysis: A review. Chinese Journal of Applied Ecology, 2015; 26: 2561-2570.

[13] He J, Qin L, Lee S K. Root-zone $\mathrm{CO}_{2}$ and root-zone temperature effects on photosynthesis and nitrogen metabolism of aeroponically grown lettuce (Lactuca sativa L.) in the tropics. Photosynthetica, 2013; 51: 330-340.

[14] He J, Lee S K. Growth and photosynthesis responses of three aeroponically grown lettuce cultivars (Lactuca sativa L.) to different root zone temperature sand growth irradiances under tropical aerial conditions. Journal of Horticultural Science \& Biotechnology, 1998; 73: 173-180.

[15] He J, Lee S K. Growth and photosynthetic characteristics of lettuce (Lactuca sativa L.) under fluctuating hot ambient temperatures with the manipulation of cool root zone temperature. Plant Physiology, 1998; 152: 387-391.

[16] Dodd I C, He J, Turnbull C G, Lee S K, Critchley C. The influence of supra-optimal root-zone temperatures on growth and stomatal conductance in Capsicum annuum L. Journal of Experimental Botony, 2000; 51: 239-248.

[17] Dannehl D, Josuttis M, Ulrichs C, Schmidt U. The potential of a confined closed greenhouse in terms of sustainable production, crop growth, yield and valuable plant compounds of tomatoes. Journal of Applied Botany and Food Quality, 2014; 87: 210-219.

[18] Song M L, Wen X Z, Li Y L. Effects of high rhizosphere temperature on plant growth and metabolism: a review. Chinese Journal of Ecology, 2010; 29: 2258-2264.

[19] Prasad P V V, Craufurd P Q, Summerfield R J. Effect of high air and soil temperature on dry matter production, pod yield and yield components of groundnut. Plant and Soil, 2000; 222: 231-239.

[20] Schwarz P A, Fahey T J, Dawson T E. Seasonal air and soil temperature effects on photosynthesis in red spruce (Picea rubens) saplings. Tree Physiology, 1997; 17: 187-194.

[21] Kurets V K, Drozdov S N, Popov E G, Talanov A V, Obshatko L A. Effect of thermo period on net photosynthesis and night respiration of cucumber plants. Russian Journal of Plant Physiology, 1999; 46: 163-167.

[22] Ambebe T F, Dang Q L, Li J. Low soil temperature inhibits the effect of high nutrient supply on photosynthetic response to elevated carbon dioxide concentration in white birch seedlings. Tree Physiology, 2010; 30. 234-243.

[23] Díaz-Pérez J C, Gitaitis R, Mandal B. Effects of plastic mulches on root zone temperature and on the manifestation of tomato spotted wilt symptoms and yield of tomato. Scientific Horticulturae, 2007; 114: 90-95.

[24] Nxawe S, Laubscher C P, Ndakidemi P A. Effect of regulated irrigation water temperature on hydroponics production of spinach (Spinacia oleracea L.). African Journal of Agricultural Research, 2009; 4: 1442-1446.

[25] Bravo F P, Uribe E G. Temperature dependence of the concentration kinetics of absorption of phosphate and potassium in corn roots. Plant Physiology, 1981; 67: 815-819.

[26] Putra P A, Yuliando H. Soilless culture system to support water use efficiency and product quality: a review. Agriculture and Agricultural Science Procedia, 2015; 3: 283-288.

[27] Fu G H, Yang Q C, Liu W K. Study on structure parameters of soil ridge to improve heat storage and release performance in Chinese solar greenhouse. Shandong Agricultural Sciences, 2015; 47: 42-45.

[28] Ta N, Wu S L, Ma W J. Peak-fitting based prediction of soil temperature according to soil moisture content in solar greenhouse. Transactions of the CSAE, 2014; 30: 204-210.

[29] Sun Z X, Zhang Q, Wang S. Research advances on the coupled heat-moisture model of soil. Journal of Arid Meteorology, 2009; 27: 373-380.

[30] Rouphael Y, Colla G, Battistelli A, Moscatello S, Proietti S, Rea E. Yield, water requirement, nutrient uptake and fruit quality of zucchini squash grown in soil and closed soilless culture. Journal of Horticultural Science \& Biotechnology, 2004; 79: 423-430.

[31] Maboko M M, Plooy C P D, Bertling I, Rodríguez-Delfín A, Martínez P F. Comparative performance of tomato on soilless vs in-soil production systems. Acta Horticulturae, 2009; 843: 319-326.

[32] Tahir I, Nakata N, Yamaguehi T J, Nakano J, Ali A M. Influence of high shoot and root-zone temperatures on growth of three wheat genotypes during early vegetative stages. Journal of Agronomy and Crop Science, 2008; 194: 141-151.

[33] Malcolm P J, Holford P, Barchia I, Mcglasson W M. High and low root zone temperatures at bud-break reduce growth and influence dry matter partitioning in peach rootstocks. Scientific Horticulturae, 2014; 171: 83-90.

[34] Rouphael Y, Colla G, Salerno A, Rivera C M, Karam F. Water use efficiency of greenhouse summer squash in relation to the method of culture: soil vs. soilless. Acta Horticulturae, 2005; 697: 81-86.

[35] Haggard B E, Moore P A, Chaubey I, Stanley E H. Nitrogen and phosphorus concentrations and export from an Ozark Plateau catchment in the United States. Biosystems Engineering, 2003; 86: 75-85.

[36] Bedessem M E, Edgar T V, Roll R. Nitrogen removal in laboratory model leach fields with organic-rich layers. Journal of Environmental Quality, 2005; 34: 936-942. 